\title{
Effects of aspirin on the gastrointestinal tract: Pros vs. cons (Review)
}

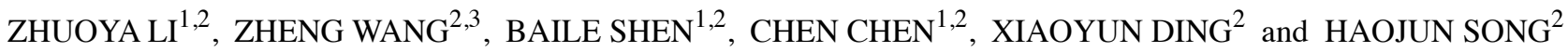 \\ ${ }^{1}$ Department of Internal Medicine, The Medical School of Ningbo University; ${ }^{2}$ Department of Gastroenterology, \\ Ningbo First Hospital, Ningbo, Zhejiang 315000; ${ }^{3}$ Department of Internal Medicine, \\ The Medical School of Zhejiang University, Hangzhou, Zhejiang 310000, P.R. China
}

Received November 21, 2019; Accepted May 28, 2020

DOI: 10.3892/ol.2020.11817

\begin{abstract}
Acetylsalicylic acid, also known as aspirin, is often used in clinical antipyretic, analgesic and antiplatelet therapy. Aspirin can cause numerous side effects in the gastrointestinal (GI) tract, ranging from unpleasant GI symptoms without gastric mucosal lesions to ulcer bleeding and even death. However, recent studies have found that aspirin can significantly prevent GI tumors. Despite impressive advances in cancer research, screening and treatment options, GI tumors remain a leading cause of death worldwide. Prevention is a far better option than treatment for tumors. Therefore, the present review assesses the pros and cons of aspirin on the GI tract and, on this the basis, the appropriate dose of aspirin to protect it.
\end{abstract}

\section{Contents}

1. Introduction

2. Pros

3. Possible mechanisms of the anticancer action of aspirin

4. Cons

5. Conclusions

Correspondence to: Dr Xiaoyun Ding, Department of Gastroenterology, Ningbo First Hospital, 59 Liuting Road, Ningbo, Zhejiang 315000, P.R. China

E-mail: dyyyding@126.com

Abbreviations: GI, gastrointestinal; LDA, low-dose aspirin; NSAIDs, non-steroidal anti-inflammatory drugs; FAP, familial adenomatous polyposis; RCT, randomized controlled trials; CRC, colorectal cancer; $\mathrm{CVD}$, cardiovascular disease; $\mathrm{NF}-\kappa \mathrm{B}$, nuclear factor $\kappa \mathrm{B}$; PPI, proton pump inhibitor; $\mathrm{HCC}$, hepatocellular carcinoma; ICC, intrahepatic cholangiocarcinoma; COX-2, cyclooxygenase 2; AMPK, adenosine monophosphate-activated protein kinase; UGSs, upper GI symptoms; H. pylori, Helicobacter pylori; CI, confidence interval

Key words: aspirin, effect, gastrointestinal cancer, gastrointestinal side effects, gastrointestinal benefit

\section{Introduction}

Cancer is a major cause of death and one of the most important global obstacles to improving life expectancy in the 21st century (1). Despite significant advances in cancer research, screening and treatment programs, gastrointestinal (GI) tumors have a high morbidity and mortality rate worldwide; according to the 2018 global cancer report, the mortality rate of colorectal cancer was 9.2\%, that of gastric cancer was $8.2 \%$ and that of liver cancer was $8.2 \%$, which account for the top 5 cancer mortality rates in the world (2). The high incidence of cancer in the digestive system, especially gastric, esophageal and colorectal cancer (CRC), is a major health burden in Asia, particularly in East Asia. Asia had the highest rate of CRC cases per 100,000 population (51.8\%) and the highest mortality rate (52.4\%) in 2018 (3). Additionally, $>727,000$ cases of gastric cancer were diagnosed in Asia in 2008, accounting for $11.9 \%$ of all confirmed cancer cases (4). Morbidity and mortality rates are also higher in East Asia than in other parts of the continent (4). China has the highest mortality rate of gastric cancer (30.1 per 100,000), followed by Japan (20.5 per $100,000)$ and South Korea $(13.8$ per 100,000) (4).

Since Bayer AG distributed acetylsalicylic acid as Aspirin ${ }^{\mathrm{TM}}$ in 1899, the drug has cornered the non-steroidal anti-inflammatory drug (NSAID) market, and with time, aspirin has become a generic name (5). Recently, aspirin has received increasing research attention. The effectiveness of low-dose aspirin (LDA) in preventing ischemic cardiovascular events has been confirmed (6-8). There is increasing evidence to support the role that aspirin may play in chemical protection, especially in patients without cardiovascular disease (CVD) (9-11). Using aspirin can reduce mortality rates and the incidence of GI tumors (12). However, aspirin can cause a range of GI side effects; aspirin taken in large doses has anti-inflammatory effects similar to those caused by non-selective NSAIDs in the GI tract (13). LDA is now widely used for cardiovascular prevention, but even at these very low doses it is still associated with upper and lower GI damage (14). In the upper GI tract, aspirin causes a series of adverse GI events, ranging from asymptomatic lesions to serious complications, such as peptic ulcer bleeding or even death (15). The link between aspirin and upper GI damage has been established, but the impact of aspirin on the lower GI tract remains unclear, although evidence has been mounting over the past few years $(15,16)$. 
The present review focuses on the advances made in understanding the benefits and the risks of long-term use of aspirin on the GI tract. To provide evidence for the rational use of aspirin in clinical practice, the appropriate dose of aspirin to protect the GI tract is analyzed and summarized.

\section{Pros}

The main benefit of aspirin in the GI tract is manifested in the chemoprophylaxis of GI adenoma and numerous types of cancer, such as CRC, gastric cancer and familial adenomatous polyposis (FAP). The main pros of aspirin, as will now be described, are also summarized in Table I. Additionally, the present review identified that the chemoprophylaxis dose of aspirin varied among studies. Therefore, the appropriate preventive doses of aspirin used in different studies are summarized in Table I.

Aspirin and colorectal adenomas. Adenomas are the most common polyps of the large intestine and are a precursor to most CRC (17). The epidemiology of adenomas and CRC is very similar, hence preventing adenomas can also prevent CRC $(18,19)$. Sandler et al (20), found that taking $325 \mathrm{mg}$ aspirin daily reduced the risk of adenomas and delayed progression in individuals with a CRC history by $10 \%$. However, the aforementioned study contain bias, as it selected only high-risk patients. Baron et al (21), conducted another study in patients who had not previously ha5d CRC and found that $81 \mathrm{mg}$ aspirin daily reduced the risk of recurrent adenomas by $19 \%$ in patients with a recent history of adenomas. In the group administered $81 \mathrm{mg}$ aspirin daily, there was a $>40 \%$ reduction in the risk of advanced disease.

FAP is a special type of colonic polyp (22). FAP is characterized by the development of multiple $(>100)$ colorectal adenomas throughout the colorectum (23). It is an uncommon autosomal dominant genetic disease characterized by numerous adenomas in the large intestine (22). Half of the patients with FAP are reported to develop adenocarcinoma by the age of 40 years (24). Prophylactic colectomy or proctocolectomy is usually performed between ages 15 and 25 years (25). However, this type of intervention can cause severe diarrhea in some patients, resulting in a dramatic decline in quality of life. Therefore, research on chemoprophylaxis is being conducted in the hope of delaying surgery, or in patients with fewer polyps, to help avoid surgery altogether using a combination of chemoprevention and endoscopic resection (26).

To the best of our knowledge, there are few reports on the effect of aspirin on FAP, but several studies have reported that aspirin can lessen the number of adenomas and delay the development of the disease. In a double-blind, randomized study where 34 patients with FAP were treated with LDA $(100 \mathrm{mg} / \mathrm{day})$ or placebo post-colectomy, the size of colorectal polyps in patients with FAP tended to be smaller when treated with LDA (27). In addition, the diameter and number of polyps were markedly reduced (aspirin:placebo group response ratio, 2.33:1) and polyp height also decreased (aspirin:placebo group response ratio, 2:1) (27). These results demonstrated that aspirin may have an impact on the relatively early stage of CRC development. However, the aforementioned study had limitations such as a small sample size and limited fields of polyp counting, which may have hampered the detection of responses. Another study by Burn et al (28), treated patients with FAP with aspirin $(600 \mathrm{mg} / \mathrm{day})$ and/or placebo for 1-12 years and reported no side effects from aspirin, but also no reduction in polyps. The differences between these 2 studies may be due to differences in cohorts of patients and the dose of aspirin given.

Current research has demonstrated that aspirin does indeed affect adenomas; aspirin prevented the growth of adenomatous polyps leading to the regression of existing polyps in several randomized trials of patients with FAP (27). However, the degree of effect of aspirin dose on adenoma is still controversial. As there are few studies on the effect of aspirin on FAP, which are hampered by the low incidence of the disease (1 in 8,300 at birth) (22) and small patient sample size, further studies are required to explore and verify their findings.

Aspirin and CRC. CRC ranked third in terms of incidence, but second in terms of mortality rate worldwide in 2018 (2). In patients with CRC with or without known CVD, there is little debate about the preventive effects of long-term aspirin use. Considerable experimental evidence supports this view.

Numerous studies have demonstrated that regular aspirin use does prevent or reduce CRC mortality rates. The effects of aspirin may be related to the duration of use. Cea Soriano et al (29) used The Health Improvement Network to estimate the incidence of CRC in individuals without CVD and demonstrated that regular LDA use is associated with a reduction in the incidence of CRC in individuals without CVD. In addition, incidence rate ratios demonstrated that starting LDA at an age of 60-69 or 70-79 years significantly reduced the CRC risk. However, starting LDA at 80-89 years did not reduce the risk of CRC. A study that used data from two ongoing prospective studies, the Nurses' Health Study and the Health Professionals Follow-up Study, which contained follow-up data for patients with CRC up to 32 years (30), discovered a dose-dependent effect of aspirin on CRC, appearing at 0.5-1.5 standard aspirin tablets weekly or the equivalent of a daily dose of LDA. A combined analysis of dose and duration demonstrated that the apparent benefit of aspirin use for GI cancer and CRC comes from taking 0.5-1.5 standard aspirin tablets weekly (30). Regular aspirin use could prevent $33 \mathrm{CRCs} / 100,000$ person-years among individuals who are older $>50$ years (30).

The majority of studies have demonstrated a decreasing risk of CRC or adenomas when aspirin therapy is stopped (31-33). There are different opinions about the duration of aspirin use. Some studies have demonstrated that this effect does not appear until 5-10 years later, which is a considerably delayed effect $(34,35)$.

Aspirin and gastric cancer. Gastric cancer was the fifth most commonly diagnosed cancer in the world and the third leading cause of cancer death in 2018 (2). Among men, it is the most common cancer in several western Asian countries, including Iran, Turkmenistan and Kyrgyzstan, and is also the main cause of cancer death (2).

A previous study using animal experiments suggested that aspirin may inhibit not only the growth of gastric cancer but also the migration of cancer cells (36). Li et al (36) used 
Table I. Association of the benefits of aspirin in the GI tract and the dose at which aspirin is effective from recent trials and studies.

A, Colorectal adenomas

\begin{tabular}{|c|c|c|c|c|c|}
\hline First author, year & Study type & No. of cases & Dose & Results & (Refs.) \\
\hline Sandler et al, 2003 & $\mathrm{RCT}$ & 635 & $325 \mathrm{mg} /$ day & $\begin{array}{l}\text { Reduced the number of adenomas and } \\
\text { delayed the development of adenomas } \\
\text { in the patients who had CRC history }\end{array}$ & $(20)$ \\
\hline Hull et al, 2018 & $\mathrm{RCT}$ & 709 & $300 \mathrm{mg} /$ day & $\begin{array}{l}\text { Reduced the total number of colorectal } \\
\text { adenomas per participant }\end{array}$ & $(117)$ \\
\hline Baron et al, 2003 & $\mathrm{RCT}$ & 1,121 & $81-325 \mathrm{mg} /$ day & Had a moderate chemopreventive effect & $(21)$ \\
\hline
\end{tabular}

B, Familial adenomatous polyposis

\begin{tabular}{|c|c|c|c|c|c|}
\hline First author, year & Study type & No. of cases & Dose & Results & (Refs.) \\
\hline Ishikawa et al, 2013 & $\mathrm{RCT}$ & 34 & $100 \mathrm{mg} /$ day & $\begin{array}{l}\text { Polyp size tended to be smaller, especially } \\
\text { in the subjects with a mean baseline polyp } \\
\text { diameter }<2 \mathrm{~mm}\end{array}$ & $(27)$ \\
\hline Burn et al, 2011 & $\mathrm{RCT}$ & 133 & $600 \mathrm{mg} /$ day & No reduction in polyps & (28) \\
\hline
\end{tabular}

$\mathrm{C}, \mathrm{CRC}$

\begin{tabular}{|c|c|c|c|c|c|}
\hline First author, year & Study type & No. of cases & Dose & Results & (Refs.) \\
\hline Cole et al, 2009 & $\begin{array}{l}\text { Meta-analysis of } \\
\text { RCTs }\end{array}$ & 3,000 & $325 \mathrm{mg} /$ day & Decreased the relative risk of adenoma & $(118)$ \\
\hline Cook et al, 2013 & RCT & 39,876 & $100 \mathrm{mg} /$ day & Decreased the risk of CRC & $(119)$ \\
\hline $\begin{array}{l}\text { Cea Soriano } \\
\text { et al, } 2017\end{array}$ & Cohort study & 263,482 & $\begin{array}{c}\text { LDA (the exact } \\
\text { dose was } \\
\text { not specified) }\end{array}$ & Reduced the incidence of CRC & $(29)$ \\
\hline Kuan et al, 2019 & Cohort study & 344,777 & $\begin{array}{c}\geq 28 \text { cumulative } \\
\text { defined daily doses }\end{array}$ & $\begin{array}{l}\text { Reduced the CRC risk in patients with } \\
\text { type } 2 \text { diabetes mellitus }\end{array}$ & $(120)$ \\
\hline $\begin{array}{l}\text { Flossman and } \\
\text { Rothwell, } 2007\end{array}$ & $\begin{array}{l}\text { Review of } 19 \\
\text { case-control } \\
\text { studies and } \\
11 \text { cohort studies }\end{array}$ & $1,136,110$ & $\geq 300$ mg/day & Reduced the incidence of CRC & $(34)$ \\
\hline $\begin{array}{l}\text { Rothwell et al, } \\
2010\end{array}$ & Cohort study & 14,033 & $\geq 75 \mathrm{mg} /$ day & $\begin{array}{l}\text { Reduced incidence and mortality } \\
\text { due to CRC }\end{array}$ & (35) \\
\hline Cao et al, 2016 & Cohort study & 135,965 & $\begin{array}{c}0.5-1.5 \text { standard } \\
\text { aspirin tablets } \\
\text { weekly }\end{array}$ & $\begin{array}{l}\text { Reduced the incidence of CRC and had } \\
\text { a dose-dependent effect of aspirin }\end{array}$ & $(30)$ \\
\hline
\end{tabular}

D, Gastric cancer

\begin{tabular}{|c|c|c|c|c|c|}
\hline First author, year & Study type & No. of cases & Dose & Results & (Refs.) \\
\hline Li et al, 2016 & $\begin{array}{l}\text { Experimental } \\
\text { study }\end{array}$ & 20 mice & $250 \mathrm{mg} / \mathrm{kg}$ & $\begin{array}{l}\text { Aspirin inhibited the proliferation and } \\
\text { migration of gastric cancer cells in mice }\end{array}$ & $(36)$ \\
\hline $\begin{array}{l}\text { Rothwell et al, } \\
2012\end{array}$ & $\mathrm{RCT}$ & 17,285 & $\geq 75 \mathrm{mg} /$ day & $\begin{array}{l}\text { Reduced the incidence of gastric cancer } \\
\text { and CRC and reduced the risk of distant } \\
\text { metastasis }\end{array}$ & $(121)$ \\
\hline Rothwell et al, 2011 & $\mathrm{RCT}$ & 25,570 & $\geq 75 \mathrm{mg} /$ day & Reduced deaths caused by gastric cancer & $(39)$ \\
\hline Thun et al, 1993 & $\begin{array}{l}\text { Meta-analysis } \\
\text { of RCTs }\end{array}$ & 635,031 & Unclear & $\begin{array}{l}\text { Reduced risk of fatal cancer of the } \\
\text { esophagus, stomach, colon and rectum }\end{array}$ & $(38)$ \\
\hline
\end{tabular}


Table I. Continued.

$\mathrm{D}$, Gastric cancer

\begin{tabular}{lcccc}
\hline First author, year & Study type & No. of cases & Dose & Results \\
\hline Cao et al, 2016 & Cohort study & 135,965 & $\begin{array}{c}0.5-1.5 \text { standard } \\
\text { aspirin tablets } \\
\text { weekly }\end{array}$ & Reduced risk of gastric cancer \\
& & & (30)
\end{tabular}

E, Esophageal cancer

\begin{tabular}{|c|c|c|c|c|c|}
\hline First author, year & Study type & No. of cases & Dose & Results & (Refs.) \\
\hline $\begin{array}{l}\text { González-Pérez } \\
\text { et al, } 2003\end{array}$ & $\begin{array}{l}\text { Meta-analysis } \\
\text { of RCTs }\end{array}$ & - & $\begin{array}{l}\text { Lack of specific } \\
\text { dose }\end{array}$ & $\begin{array}{l}\text { Reduced the risk of esophageal cancer } \\
\text { and gastric cancer }\end{array}$ & $(42)$ \\
\hline Liu et al, 2009 & $\mathrm{RCT}$ & 1,716 & $25-50 \mathrm{mg} /$ day & $\begin{array}{l}\text { Reduced the risk of both esophageal } \\
\text { cancer and esophageal squamous cell } \\
\text { carcinoma }\end{array}$ & (43) \\
\hline Vaughan et al, 2005 & $\begin{array}{l}\text { Prospective } \\
\text { cohort study }\end{array}$ & 350 & $\geq 75 \mathrm{mg} /$ day & $\begin{array}{l}\text { Reduced the risk of neoplastic progression } \\
\text { in Barrett's esophagus }\end{array}$ & $(41)$ \\
\hline Farrow et al, 1998 & $\begin{array}{l}\text { Case-control } \\
\text { study }\end{array}$ & 695 & $\begin{array}{l}\text { No specific dose } \\
\text { was indicated }\end{array}$ & $\begin{array}{l}\text { Reduced the risk of cancers of the } \\
\text { esophagus and stomach }\end{array}$ & $(40)$ \\
\hline Bosetti et al, 2012 & $\begin{array}{l}\text { Review } \\
\text { comprising of } \\
\text { case-control and } \\
\text { cohort studies }\end{array}$ & - & Unclear & $\begin{array}{l}\text { Reduced the risk of esophageal cancer } \\
\text { and gastric cancer }\end{array}$ & (46) \\
\hline Spence et al, 2018 & $\begin{array}{l}\text { Case-control } \\
\text { study }\end{array}$ & 8,487 & $75 \mathrm{mg} /$ day & $\begin{array}{l}\text { Long-term aspirin was not associated } \\
\text { with cancer-specific mortality after } \\
\text { diagnosis of esophageal or gastric cancer }\end{array}$ & $(48)$ \\
\hline
\end{tabular}

F, Other GI tumors

\begin{tabular}{|c|c|c|c|c|c|}
\hline First author, year & Study type & No. of cases & Dose & Results & (Refs.) \\
\hline Rothwell et al, 2011 & $\mathrm{RCT}$ & 25,570 & 75 mg/day & Reduced the mortality of pancreatic cancer & (39) \\
\hline Petrick et al, 2015 & $\begin{array}{l}\text { Case-control } \\
\text { study }\end{array}$ & $1,084,133$ & $\leq 163 \mathrm{mg} /$ day & $\begin{array}{l}\text { Prevented liver cancer (including } \\
\text { hepatocellular and intrahepatic } \\
\text { cholangiocarcinoma) }\end{array}$ & $(52)$ \\
\hline Choi et al, 2019 & $\begin{array}{l}\text { Case-control } \\
\text { study }\end{array}$ & 4,962 & $\begin{array}{l}\text { LDA but the } \\
\text { exact dose } \\
\text { remains unclear }\end{array}$ & $\begin{array}{l}\text { Reduced risk of pancreatic ductal } \\
\text { adenocarcinoma incidence for patients } \\
\text { with risk factors }\end{array}$ & (49) \\
\hline
\end{tabular}

CRC, colorectal cancer; GI, gastrointestinal; RCT, randomized control trial; LDA, low-dose aspirin.

$\mathrm{p} 53 \%$ mice $(\mathrm{n}=20)$ that were randomly divided into 2 groups to understand the effects of aspirin on gastric cancer. The aforementioned study demonstrated that the proliferation capacity of tumor cells in the experimental group $(250 \mathrm{mg} / \mathrm{kg}$ aspirin daily added to food) was significantly reduced compared with that of the control group, and the number of cells was also markedly reduced.

To the best of our knowledge, there are few specific studies on the effects of aspirin on gastric cancer. The extent of the impact of aspirin on gastric cancer seems to be smaller than that on CRC and colorectal adenoma; in addition, the data are less comprehensive and more variable. However, it can be concluded from multi-factor analysis in numerous studies that aspirin can inhibit the growth of gastric cancer. Two cohort studies have found that there was a $41 \%$ reduction in mortality in patients with gastric cancer when aspirin was taken $(37,38)$. In a study involving several randomized controlled trials (RCTs), reported deaths decreased by $31 \%$ in patients with 
gastric cancer who took aspirin $(\mathrm{P}=0.11)$, and most significant decreases of up to $58 \%(\mathrm{P}=0.007)$ were observed after 10 years of use (39).

Aspirin and esophageal cancer. The incidence and mortality of esophageal cancer were ranked seventh and sixth among all types of cancer, respectively, in the 2018 global cancer statistics (2). Due to the poor prognosis of esophageal cancer, treatment options have been highlighted in this section of the review.

The effect of long-term aspirin use in Barrett's esophageal cancer has been studied by several clinical trials and population-based observational studies, suggesting that aspirin may slow down its progression to both squamous carcinoma and adenocarcinoma (40-42). Another three independent studies reported that in patients with esophageal cancer, aspirin had a remarkable protective effect on all-cause mortality (43-45). In all three studies, these effects were limited to patients with esophageal cancer (44) and esophageal squamous cell carcinoma (43), and in the most recent study (45), when methods to reduce immortal time bias were employed, the effects were attenuated. A meta-analysis indicated that aspirin does have a protective effect on esophageal cancer (including gastric cardia cancer), regardless of squamous cell or adenocarcinoma type (46). In addition, in a recent study, in patients with Barrett's esophageal cancer who did not have a history of NSAID use, aspirin showed a significant protective effect (47).

However, opposing results were found by a study that included two large independent population-based cohorts in the UK (48). The study aforementioned revealed that long-term aspirin use (75 $\mathrm{mg} /$ day) was not associated with cancer-specific mortality after the diagnosis of esophageal or gastric cancer (48). These differences may be due to the aforementioned study investigating the effects of using aspirin on cancer after a diagnosis of gastric or esophageal cancer, whereas in other studies, patients were taking aspirin prior to esophageal or gastric cancer diagnosis.

Aspirin and other GI tumors. Aspirin can reduce cancer-related mortality in all solid cancer types. One study found that this was mainly due to fewer deaths after 5 years, including significant reductions in pancreatic cancer deaths (39). In the aforementioned study, aspirin had a significant effect on pancreatic cancer death only after $>7.5$ years of planned treatment [hazard ratio (HR), 0.28; 95\% confidence interval (CI) $0.08-1.00 ; \mathrm{P}=0.04]$. Another study found that aspirin use was associated with a reduced risk of pancreatic ductal adenocarcinoma incidence in patients with risk factors (OR, 0.48; $95 \%$ CI, 0.31-0.67; P<0.001) (49).

Previous studies have suggested that aspirin may have the potential to prevent liver cancer [including hepatocellular carcinoma (HCC) and intrahepatic cholangiocarcinoma (ICC)] $(50,51)$. A prospective cohort study based on data from 1,084,133 individuals ( $\mathrm{HCC}, \mathrm{n}=679$; ICC, $\mathrm{n}=225$ ) from 10 counties in the United States found that aspirin users who took the drug once a day ( $>5$ years; $\leq 163 \mathrm{mg}$ ) had a $32 \%$ reduction in the risk of liver cancer (52). In addition, aspirin use reduced ICC risk by $36 \%$ in men, but not in women. For some patients with liver cancer who are at higher risk of bleeding (due to, for example, cirrhosis of the liver and portal hypertension with thrombocytopenia), aspirin should be avoided due to the risk of GI bleeding and renal failure (53). Therefore, the use of aspirin in these patients remains an important matter and should be investigated further.

\section{Possible mechanisms of the anticancer action of aspirin}

The process by which normal cells turn into cancer cells is very complex and despite extensive study, the mechanisms by which aspirin may affect carcinogenesis remain unknown. However, in the early stages of cancer development, a common feature is that cells no longer respond to anti-proliferation and -differentiation signals, instead automatically producing signals to promote growth (54). The role of aspirin may be related to these processes.

One of the mechanisms involved in the anticancer activity of aspirin is commonly thought to be its ability to inhibit the activity of cyclooxygenase (COX) $(55,56)$. COX-2 is strongly and rapidly induced in response to growth factors, cytokines, endotoxins and inflammation, and involves cell proliferation and the promotion of tumor development (57). As aspirin is a potent inhibitor of $\mathrm{COX}-2$, it can reduce the production of prostaglandins and other inflammatory mediators (58). The deleterious effects of prostaglandins include promoting cell survival, stimulating cell proliferation and promoting angiogenesis, which can increase cancer metastasis $(59,60)$.

However, the chemoprophylaxis of aspirin cannot be explained by inhibiting prostaglandin synthesis only, since some NSAIDs are still resistant to proliferation in cells that have no COX activity (61). COX-independent evidence has also been found in recent years, particularly in high-dose aspirin $(31,62-65)$, which has been reported to induce apoptosis through the inhibition of activation of nuclear factor $\kappa \mathrm{B}(\mathrm{NF}-\kappa \mathrm{B})$, the upregulation of tumor suppressor genes, such as TP53, CDKN1A and BAX, and the downregulation of antiapoptotic genes such as BCL-2 (55). Maintaining homeostasis requires apoptosis, or programmed cell death, to maintain a dynamic balance of the total number of cells in a tissue (66). Previous studies $(67,68)$ reported reduced microsatellite instability and enhanced apoptosis in mismatch repair (MMR)-deficient cells exposed to aspirin, and suggested that aspirin may induce genetic selection for microsatellite stability in a subset of MMR-deficient cells. Aspirin may delete those aberrant stem cells most likely to progress rapidly to cancer (69). Recently, autophagy has been found to play a role in the chemoprevention of cancer by aspirin. It has been reported that LDA can induce autophagic death and inhibit the proliferation of various tumor cells, including HCC and CRC cells (70,71). Adenosine monophosphate-activated protein kinase (AMPK) can inhibit the growth and proliferation of tumor cells by affecting autophagy and inhibiting glycolysis. Recent studies have demonstrated that aspirin can promote the autophagy and apoptosis of tumor cells by activating AMPK (72,73). Aspirin can activate AMPK by the allosteric effect and by inhibiting the dephosphorylation of AMPK $\alpha$ at the Thr 172 site; AMPK $\alpha$ is an important activator of AMPK (74).

In addition, it has been reported that aspirin can stop or delay the growth and mutation of tumor cells instead of killing them directly. Aspirin can reduce the abnormal accumulation 
of genes in cancer tissues (75). Aspirin may also play a role in the DNA mismatch-repair system, Wnt signaling, NF- $\kappa \mathrm{B}$ signaling and polyamine metabolism $(76,77)$. Despite several recognized mechanisms of action for the anticancer effect of aspirin, the exact mechanism remains unknown.

\section{Cons}

The main cons of aspirin, as will now be described, are also summarized in Table II.

\section{Aspirin and upper GI adverse effects}

Upper GI symptoms (UGSs). UGSs are the leading cause of discontinuation in patients treated with aspirin $(78,79)$. Aspirin is one of the most common causal agents of medication hangover leading to hospitalization (80). UGSs are common but often overlooked. In particular, short-term use of aspirin for the treatment of pain, colds or fever did not show serious adverse events, but increased the risk of mild GI illness (81). A study known as 'The UGLA survey' demonstrated that the most frequent GI reaction among individuals using LDA was gastroesophageal reflux, followed by gastric burning and acid regurgitations (82). Most of the subjects (72\%) reported that UGSs negatively affected their daily lives, even at low doses of aspirin, and damaged their quality of life to varying degrees (82). UGSs were present in one-fifth of patients taking LDA, resulting in poor compliance. In addition, a history of dyspepsia led to the occurrence of UGSs associated with LDA (82).

Peptic ulcers and bleeding. Ulcers are lesions that extend throughout the thickness of the mucosa and into the submucosa or deeper layers (83). Evidence of aspirin-induced peptic ulcers, particularly stomach ulcers began to emerge in the 1960s. Small ulcers are common even at the low doses of aspirin currently used for cardiovascular protection $(78,84)$. One trial involving patients from four different countries who took $75-325 \mathrm{mg}$ of aspirin daily for baseline endoscopic evaluation found that the annualized incidence of new ulcers was $28 \%$, and the majority of ulcers were in the stomach (78). Another trial found similar rates in LDA users (84). Helicobacter pylori (H.pylori) infection and advanced age ( $>70$ years) significantly increased the risk of ulcers (78). Other studies demonstrated that in NSAID users, H. pylori infection increased the risk of uncomplicated peptic ulcer by 2-3.5 times and GI bleeding by 2-2.5 times (85-87). Complications of peptic ulcers, especially the risk of bleeding, are associated with aspirin (88). A review analyzing studies published between 1946 and 2015 on the risk between long-term LDA and GI bleeding found that the incidence of GI bleeding with LDA was 0.48-3.64 cases per 1,000 person-years (89). A recent study involving healthy elderly individuals who did not have known CDV found that aspirin was associated with a notably higher risk of bleeding (90). The main bleeding events involved the upper GI tract and intracranial hemorrhage. A review of risk analysis of prophylactic use of aspirin in the general population demonstrated a significant increase in bleeding and ulcer events at 70 years of age, with long-term aspirin use reducing the risk of aspirin-related excessive bleeding (87).

GI perforation. Perforation is also a serious GI side effect of aspirin. A case-control study found that in the general population, LDA used to prevent CVD conferred a two-fold increased risk of upper GI perforation (91). Aspirin had the same effect on the gastric and duodenal sites. The aforementioned study reported that patients have the greatest risk of serious GI complications in the first 2 months after starting aspirin, following which, the risk falls and reaches a plateau at $\sim 6$ months. Aspirin is the most important independent risk factor for perforation of the upper and lower alimentary tract, and a history of smoking, alcohol consumption, arthritis or peptic ulcers increases the risk of perforation (92).

Aspirin and lower GI adverse effects. The association between LDA use and upper GI injuries has been well established, but effects of aspirin on the lower GI tract remain unclear, despite increasing evidence in recent years. A Japanese study reported that LDA $(100 \mathrm{mg})$ significantly increased the risk of lower GI bleeding, but the number of bleeding cases $(n=44)$ was relatively small (93). In a Spanish case-control study $(>1,000$ bleeding observations), LDA increased the risk of lower GI bleeding (including bleeding from the small and large intestine) by 2.7 times compared with no aspirin use (94). A study in Japan reported that CVD patients prescribed LDA for $>1$ year have a high risk of hemorrhage, but few cases (5/701) of bleeding were observed, so the CI was large and the finding not statistically significant (95).

In addition, the association between LDA and the development of diverticular bleeding and diverticulitis have been evaluated by several studies $(16,96,97)$. In Japan, recent prospective research on diverticular disease has assessed the efficacy of LDA and found a significant association with diverticular bleeding (97). A study by health professionals demonstrated an increase in the risk of diverticular bleeding with LDA (2-5.9 tablets of $325 \mathrm{mg}$ per week; multivariate HR, 2.32 ; $95 \% \mathrm{CI}, 1.34-4.02)$ compared with no aspirin use (98).

Aspirin and hepatic injury. Hepatotoxicity induced by NSAIDs is a rare but potentially fatal complication that usually occurs within 12 weeks of initiation of treatment; it can occur in all NSAIDs, but seems to be more common when diclofenac and sulindac are used (99). Although there are few reports on the association between aspirin and hepatotoxicity, the side effect of hepatotoxicity in patients with hepatic dysfunction should be noted. The patients may present with acute fulminant liver failure or with no symptoms, but with the biochemical and histological characteristics of chronic active hepatitis (99). The hepatotoxicity of aspirin is dose-dependent and generally does not result in liver damage (75-300 mg/day) unless the full anti-inflammatory doses are used (99).

\section{Conclusions}

In general, the benefits of aspirin to the GI tract are mainly reflected in cancer prevention. Aspirin can reduce the incidence of gastric cancer, CRC, colorectal adenoma, live cancer and pancreatic cancer, and reduce the risk of Barrett's esophageal progression to esophageal adenocarcinoma. The protective effect of aspirin on CRC and colorectal adenomas is almost certain, especially in older adults at risk for CVD. In April 2016, the United States Preventive Services Task Force formally issued guidelines recommending LDA 
Table II. Side effects of aspirin on the GI tract and related preventive measures.

\begin{tabular}{|c|c|c|c|c|}
\hline Region affected & Main risk factors & Dose & Adverse drug reaction & Precaution \\
\hline Upper GI tract & $\begin{array}{l}\text { H. pylori infection and } \\
\text { advanced age }(>70)\end{array}$ & $\begin{array}{l}\text { LDA but the exact dose } \\
\text { remains unclear. }\end{array}$ & $\begin{array}{l}\text { UGSs, peptic ulcers and } \\
\text { bleeding, perforation }\end{array}$ & $\begin{array}{l}\text { PPI prophylaxis may be } \\
\text { considered for patients } \\
\text { with related risk factors } \\
\text { (Fig. 1) }\end{array}$ \\
\hline Lower GI tract & $\begin{array}{l}\text { Older patients with a } \\
\text { great number of } \\
\text { comorbidities }(122,123)\end{array}$ & $\begin{array}{l}\text { Even LDA was associated } \\
\text { with damage (124) and } \\
\text { increased doses can cause } \\
\text { more severe bleeding (125) }\end{array}$ & Lower GI bleeding & $\begin{array}{l}\text { Some studies have } \\
\text { evaluated the efficacy } \\
\text { of probiotics in } \\
\text { preventing lower GI } \\
\text { injury among patients } \\
\text { treated with LDA, but } \\
\text { there is insufficient } \\
\text { evidence to recommend } \\
\text { a specific probiotic } \\
(126,127) \text {. }\end{array}$ \\
\hline Lower GI tract & $\begin{array}{l}\text { Obesity, hypertension, } \\
\text { anticoagulants, diabetes } \\
\text { mellitus, and ischemic } \\
\text { heart disease (16) }\end{array}$ & $\begin{array}{l}\text { There is no dose-dependent } \\
\text { effect but a greater risk } \\
\text { with the increasing duration } \\
\text { of regular aspirin use (98) }\end{array}$ & $\begin{array}{l}\text { Diverticular bleeding } \\
\text { and diverticulitis }\end{array}$ & $\begin{array}{l}\text { There is no established } \\
\text { prophylaxis for } \\
\text { diverticular bleeding } \\
\text { and diverticulitis. }\end{array}$ \\
\hline Liver & $\begin{array}{l}\text { Patients with hepatic } \\
\text { dysfunction (99) }\end{array}$ & $\begin{array}{l}\text { Dose-dependent, } \\
75-300 \mathrm{mg} / \text { day does not } \\
\text { result in liver damage }\end{array}$ & $\begin{array}{l}\text { Hepatic injury (acute } \\
\text { fulminant liver failure } \\
\text { or with no symptoms } \\
\text { but with the biochemical } \\
\text { and histological } \\
\text { characteristics of chronic } \\
\text { active hepatitis) }\end{array}$ & $\begin{array}{l}\text { Avoid large doses of } \\
\text { aspirin. }\end{array}$ \\
\hline
\end{tabular}

GI, gastrointestinal; LDA, low-dose aspirin; PPI, proton pump inhibitor; H. pylori, Helicobacter pylori.

(75-100 $\mathrm{mg} /$ day) to prevent CVD and CRC in people aged 50-69 years with CVD risk but no elevated hemorrhage risk (11). However, the preventive effect for other GI cancer types is still controversial. The effect of aspirin on cancer prevention is mainly reflected after 4-5 years, even at low doses. However, a recent study (ASPREE trial) found that aspirin did not help reduce all-cause mortality (mainly cancer-related mortality, including GI cancer) (100). There are several possible reasons why the results of this study differ from those of previous studies: i) Most previous studies did not regard cancer as a predefined secondary endpoint, nor did they establish systematic approaches for the diagnosis and adjudication of cancer endpoints; and ii) the participants in the aforementioned study were mainly healthy individuals aged $\geq 70$ years, with a median follow-up of 4.7 years, while previous studies mainly focused on people aged $<70$ and found that the effects of aspirin take 4-5 years to show. The other primary prevention trials of aspirin did not find similar results, suggesting that the deaths reported in the aforementioned study should be interpreted with caution.

Speculation remains as to the risk-benefit ratio of long-term aspirin use and the optimal dose required for effective chemoprevention while minimizing side effects. One of the most representative studies of the effects of different doses of aspirin on the risk of GI cancer is that conducted by Rothwell et al (35). The study found the same effect for 75-300 $\mathrm{mg}$ doses of aspirin with regard to the reduction of fatal CRC, with $75 \mathrm{mg}$ daily being as effective as higher doses. The group also observed an absolute risk reduction in colorectal malignancy of $\sim 1.5 \%$ after a 5 -year period of treatment with at least $75 \mathrm{mg}$ aspirin. However, very low doses of aspirin (e.g., $30 \mathrm{mg} /$ day) are associated with a higher risk of fatal CRC compared with higher doses $(34,35)$. The effective dose of aspirin in order to obtain the associated benefits of the drug in the GI tract varies between trials, although some studies have demonstrated that high-dose aspirin (>500 mg/day) may confer stronger protection than standard dose regimens $(28,101)$. As summarized in Table I, numerous recent trials have challenged this notion, providing evidence for the use of LDA in cancer prevention. This phenomenon may be related to the different pharmacokinetics and pharmacodynamics of aspirin in different environments, and the physiological differences among patient populations $(102,103)$.

The main harmful effects of aspirin on the digestive system are bleeding, ulcers, perforation, dyspepsia and discomfort, while hepatic dysfunction is rare (Table II). One study found that aspirin has low toxicity and leads to a lower incidence of bleeding in the upper GI tract, and that it mainly results in 


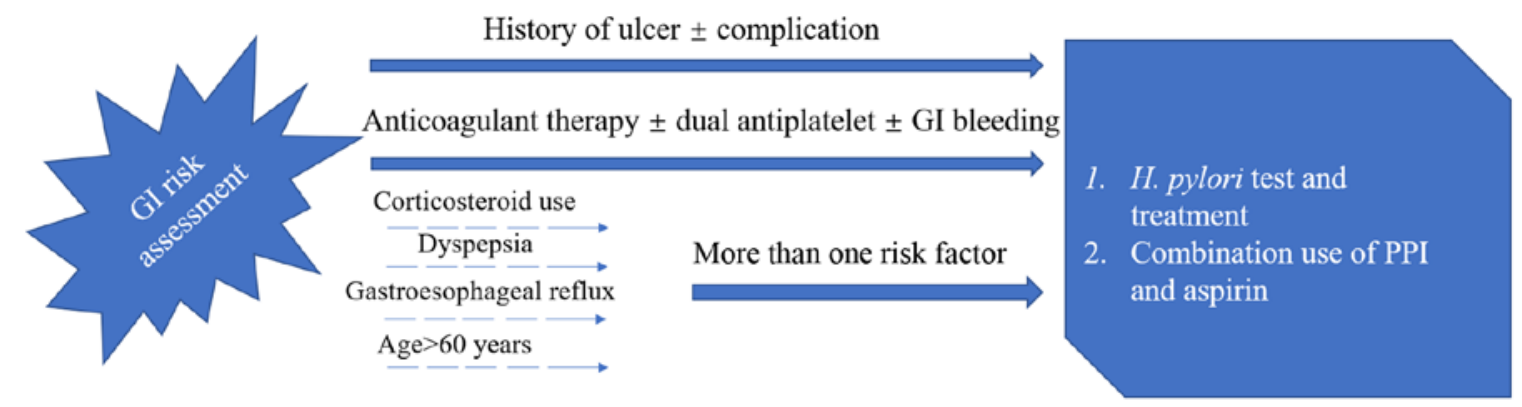

Figure 1. According to the report of the American College of Cardiology Foundation Task Force (107), PPI recommendation for various low-dose aspirin users. PPI, proton pump inhibitor; H. pylori, helicobacter pylori; GI, gastrointestinal.

dyspepsia. This study demonstrated that the beneficial effects of aspirin on cancer outweigh the risk of aspirin-induced bleeding events (104). The main risk factors for bleeding in aspirin users are age and $H$. pylori infection $(7,105)$. Age is a key factor when weighing the pros and cons of aspirin. Once an individual approaches 60 years old, there is a marked increase in the risk of aspirin-induced bleeding events, with a non-linear relationship between increased risk and subsequent age $(106,107)$. Changing drug formulations would not alleviate the adverse effects of aspirin on upper GI mucosa, and neither buffer nor enteric-coated tablets can reduce the risk of massive upper GI bleeding $(107,108)$. According to previous studies, long-term LDA use for $>4-5$ years still plays a role in the prevention of GI cancer in healthy people aged 55-65 years. Since aspirin takes 4-5 years to have an effect and there is an increased risk of GI side effects in people aged $>60$, the prophylactic use of aspirin alone in people aged $>60$ is not recommended. Numerous studies have demonstrated that proton pump inhibitors (PPI) significantly reduce the risk of GI adverse events in aspirin patients $(14,89,109-111)$. H2-receptor antagonists can also inhibit the secretion of gastric acid to a certain extent, but their effect may not be as good as that of PPI preparation (112). This superiority was observed uniformly in the separate clinical circumstances in which these agents are used in peptic ulcer disease, namely the prevention, healing and treatment of acute upper GI bleeding (113). According to the report by the American College of Cardiology Foundation Task Force (Fig. 1) (107), PPI were recommended in association with low-dose aspirin for patients with prior history of ulcer diseases or complicated GI ulcer. For other patients who have more than one risk factor among the categories of corticosteroid use, dyspepsia or gastroesophageal reflux and age $>60$ years, PPI are recommended. As H. pylori is an important risk factor for ulcer and ulcer bleeding in patients on LDA, a systematic testing for and eradication of $H$. pylori is recommended before starting aspirin for patients with prior history of ulcer disease (107). The value of PPI combined with aspirin lies not only in its ability to decrease the incidence of adverse events in the upper GI, but also in its ability to decrease the risk of withdrawal of aspirin $(114,115)$. This has been confirmed in both RCTs and observational studies $(114,115)$.

Clinicians always face clinical dilemmas and need to balance the risks and benefits of treatment. The use of aspirin in preventing GI cancer (or adenoma) and the risk of GI damage is one of these situations. In conclusion, the continued prophylactic use of LDA (75-325 mg/day) for at least 4-5 years to prevent GI cancer in non-high-risk populations aged 55-65 years should be considered for several reasons: i) A large amount of evidence suggests that LDA may play a prophylactic role in GI cancer. In addition, LDA causes less damage to the GI tract compared with high-dose aspirin. ii) The negative effects of aspirin to the GI tract are mainly the damage to the upper GI tract. The efficacy of PPI in treating LDA-related gastroduodenal ulcers and bleeding in most populations has been well documented and recognized. iii) Although, there is no effective preventive measure for lower GI bleeding, the clinical significance of LDA-induced lower GI mucosal injury is still unclear. Most studies investigating lower GI bleeding events had small sample sizes with wide CIs. LDA is routinely used in the primary and secondary prophylaxis of CVD. With a globally aging population (116), the consumption of LDA seems likely to increase in the future. Effects of aspirin need to be seen from a risk-benefit perspective, and from all the aforementioned evidence, we believe that the benefits outweigh the risks. However, unanswered questions related to the exact mechanism of cancer-related effects, optimal dose, duration, treatment options, and the balance of risks and benefits among specific populations need to be further investigated. The present review will contribute to continued progress in this exciting area of research.

\section{Acknowledgments}

Not applicable.

\section{Funding}

This study was supported by grants from the Natural Science Foundation of Ningbo (grant no. 2016A610158), the Natural Science Foundation of Ningbo (grant no. 2014A610226) and the Scientific Benefit for People Project of Ningbo (grant no. 2014C51001).

\section{Availability of data and materials}

Not applicable.

\section{Authors' contributions}

ZL wrote the paper and collected the data. BS and ZW conceived and designed the review. CC and HS collected important background information, prepared the preliminary 
work of the manuscript and assisted in preliminary data collection. XD reviewed and edited the manuscript. All authors have read and approved the final manuscript.

\section{Ethics approval and consent to participate}

Not applicable.

\section{Patient consent for publication}

Not applicable.

\section{Competing interests}

The authors declare that they have no competing interests.

\section{References}

1. Jemal A, Center MM, DeSantis C and Ward EM: Global patterns of cancer incidence and mortality rates and trends. Cancer Epidemiol Biomarkers Prev 19: 1893-1907, 2010.

2. Bray F, Ferlay J, Soerjomataram I, Siegel RL, Torre LA and Jemal A: Global cancer statistics 2018: GLOBOCAN estimates of incidence and mortality worldwide for 36 cancers in 185 countries. CA Cancer J Clin 68: 394-424, 2018.

3. Onyoh EF, Hsu WF, Chang LC, Lee YC, Wu MS and Chiu HM: The rise of colorectal cancer in asia: Epidemiology, screening, and management. Curr Gastroenterol Rep 21: 36, 2019.

4. Rahman R, Asombang AW and Ibdah JA: Characteristics of gastric cancer in Asia. World J Gastroenterol 20: 4483-4490, 2014.

5. Wick JY: Aspirin: A history, A love story. Consult Pharm 27: 322-329, 2012

6. Amsterdam EA, Wenger NK, Brindis RG, Casey DE, Ganiats TG, Holmes DR, Jaffe AS, Jneid H, Kelly RF, Kontos MC, et al: 2014 AHA/ACC Guideline for the management of patients with Non-ST-Elevation acute coronary syndromes: Executive summary: A Report of the American College of Cardiology/American Heart Association Task Force on Practice Guidelines. J Am Colle Cardiol 64: 2645-2687, 2014.

7. Antithrombotic Trialists' (ATT) Collaboration; Baigent C, Blackwell L, Collins R, Emberson J, Godwin J, Peto R, Buring J, Hennekens C, Kearney P, et al: Aspirin in the primary and secondary prevention of vascular disease: Collaborative meta-analysis of individual participant data from randomised trials. Lancet 373: 1849-1860, 2009.

8. Roffi M, Patrono C, Collet J, Mueller C, Valgimigli M, Andreotti F, Bax J, Borger M, Brotons C, Chew DP, et al: 2015 ESC Guidelines for the management of acute coronary syndromes in patients presenting without persistent ST-segment elevation. Task Force for the management of acute coronary syndromes in patients presenting without persistent ST-Segment Elevation of the European Society of Cardiology (ESC). G Ital Cardiol (Rome) 17: 831-872, 2016 (In Italian).

9. Smith DK, Demetriou T and Weber C: Aspirin for primary prevention: USPSTF recommendations for CVD and colorecta cancer. J Fam Pract 68: 146-151, 2019.

10. Ventura L, Miccinesi G, Barchielli A, Manneschi G, Puliti D, Mantellini P, Orso F and Zappa M: Does low-dose aspirin use for cardiovascular disease prevention reduce colorectal cancer deaths? A comparison of two cohorts in the Florence district, Italy. Eur J Cancer Prev 27: 134-139, 2018.

11. Bibbins-Domingo K and U.S. Preventive Services Task Force: Aspirin use for the primary prevention of cardiovascular disease and colorectal cancer: U.S. Preventive Services Task Force recommendation statement. Ann Intern Med 164: 836-845, 2016

12. Cea Soriano L, Soriano-Gabarró M and García Rodríguez LA Incidence of colorectal cancer in new users and non-users of low-dose aspirin without existing cardiovascular disease: A cohort study using The Health Improvement Network. Int J Cardiol 248: 376-381, 2017.

13. Soon S, Chia WJ, Redekop K and Wee HL: A Cost-effectiveness analysis of aspirin in the primary prevention of cardiovascular diseases and colorectal cancer. Value Health 18: A462, 2015.
14. Lanas A and Gargallo CJ: Management of low-dose aspirin and clopidogrel in clinical practice: A gastrointestinal perspective. J Gastroenterol 50: 626-637, 2015.

15. Lanas A and Scheiman J: Low-dose aspirin and upper gastrointestinal damage: Epidemiology, prevention and treatment. Curr Med Res Opin 23: 163-173, 2007.

16. Yuhara H, Corley DA, Nakahara F, Nakajima T, Koike J, Igarashi M, Suauki $\mathrm{T}$ and Mine T: Aspirin and non-aspirin NSAIDs increase risk of colonic diverticular bleeding: A systematic review and meta-analysis. J Gastroenterol 49: 992-1000, 2014.

17. Strum WB: Colorectal adenomas. N Engl J Med 374: 1065-1075, 2016.

18. Giovannucci E, Rimm E, Stampfer M, Colditz G, Ascherio A and Willett WC: Aspirin use and the risk for colorectal cancer and adenoma in male health professionals. Ann Intern Med 121: 241-246, 1994.

19. Thun MJ, Namboodiri MM and Heath C Jr: Aspirin use and reduced risk of fatal colon cancer. N Engl J Med 325: 1593-1596, 1991.

20. Sandler R, Halabi S, Baron J, Budinger S, Paskett E, Keresztes R, Petrelli N, Pipas J, Karp D, Loprinzi CL, et al: A randomized trial of aspirin to prevent colorectal adenomas in patients with previous colorectal cancer. N Engl J Med 348: 883-890, 2003.

21. Baron JA, Cole BF, Sandler RS, Haile RW, Ahnen D, Bresalier R, McKeown-Eyssen G, Summers RW, Rothstein R, Burke CA, et al: A randomized trial of aspirin to prevent colorectal adenomas. N Engl J Med 348: 891-899, 2003.

22. Half E, Bercovich D and Rozen P: Familial adenomatous polyposis. Orphanet J Rare Dis 4: 22, 2009.

23. Aihara H, Kumar N and Thompson CC: Diagnosis, surveillance, and treatment strategies for familial adenomatous polyposis: Rationale and update. Eur J Gastroenterol Hepatol 26: 255-262, 2014.

24. Iwama T, Tamura K, Morita T, Hirai T, Hasegawa H, Koizumi K, Shirouzu K, Sugihara K, Yamamura T, Muto T, et al: A clinical overview of familial adenomatous polyposis derived from the database of the polyposis registry of Japan. Int J Clin Oncol 9: 308-316, 2004

25. Jasperson K and Burt RW: The genetics of colorectal cancer. Surg Oncol Clin N Am 24: 683-703, 2015.

26. Ishikawa $\mathrm{H}$ : Chemoprevention of carcinogenesis in familial tumors. Int J Clin Oncol 9: 299-303, 2004.

27. Ishikawa H, Wakabayashi K, Suzuki S, Mutoh M, Hirata K, Nakamura T, Takeyama I, Kawano A, Gondo N, Abe T, et al: Preventive effects of low-dose aspirin on colorectal adenoma growth in patients with familial adenomatous polyposis: Double-blind, randomized clinical trial. Cancer Med 2: 50-56, 2013.

28. Burn J, Bishop DT, Chapman PD, Elliott F, Bertario L, Dunlop MG, Eccles D, Ellis A, Evans DG, Fodde R, et al: A randomized placebo-controlled prevention trial of aspirin and/or resistant starch in young people with familial adenomatous polyposis. Cancer Prev Res (Phila) 4: 655-665, 2011.

29. Cea Soriano L, Soriano-Gabarró M and Garcia Rodríiguez LA: Incidence of colorectal cancer in new users and non-users of low-dose aspirin without existing cardiovascular disease: A cohort study using The Health Improvement Network. Int J Cardiol 248: 376-381, 2017.

30. Cao Y, Nishihara R, Wu K, Wang M, Ogino S, Willett WC, Spiegelman D, Fuchs CS, Giovannucci EL and Chan AT: Population-wide impact of long-term use of aspirin and the risk for cancer. JAMA Oncol 2: 762-769, 2016.

31. Thun MJ, Henley SJ and Patrono C: Nonsteroidal Anti-inflammatory drugs as anticancer agents: Mechanistic, pharmacologic, and clinical issues. J Nat Cancer Inst 94: 252-266, 2002.

32. Rothwell PM,Price JF, Fowkes FG, Zanchetti A, Roncaglioni MC, Tognoni G, Lee R, Belch JF, Wilson M, Mehta Z and Meade TW: Short-term effects of daily aspirin on cancer incidence, mortality, and non-vascular death: Analysis of the time course of risks and benefits in 51 randomised controlled trials. Lancet 379: 1602-1612, 2012.

33. Chubak J, Whitlock EP, Williams SB, Kamineni A, Burda BU, Buist DS and Anderson ML: Aspirin for the prevention of cancer incidence and mortality: Systematic evidence reviews for the U.S. Preventive Services Task Force. Ann Intern Med 164: 814-825, 2016.

34. Flossmann E and Rothwell PM; British Doctors Aspirin Trial and the UK-TIA Aspirin Trial: Effect of aspirin on long-term risk of colorectal cancer: Consistent evidence from randomised and observational studies. Lancet 369: 1603-1613, 2007. 
35. Rothwell PM, Wilson M, Elwin CE, Norrving B, Algra A, Warlow CP and Meade TW: Long-term effect of aspirin on colorectal cancer incidence and mortality: 20-year follow-up of five randomised trials. Lancet 376: 1741-1750, 2010.

36. Li XF, Xu BZ and Wang SZ: Aspirin inhibits the proliferation and migration of gastric cancer cells in p53-knockout mice. Oncol Lett 12: 3183-3186, 2016.

37. Ratnasinghe LD, Graubard BI, Kahle L, Tangrea JA, Taylor PR and Hawk E: Aspirin use and mortality from cancer in a prospective cohort study. Anticancer Res 24: 3177-3184, 2004.

38. Thun MJ, Namboodiri MM, Calle EE, Flanders WD and Heath CW Jr: Aspirin use and risk of fatal cancer. Cancer Res 53: 1322-1327, 1993.

39. Rothwell PM, Fowkes FGR, Belch JFF, Ogawa H, Warlow CP and Meade TW: Effect of daily aspirin on long-term risk of death due to cancer: Analysis of individual patient data from randomised trials. Lancet 377: 31-41, 2011.

40. Farrow DC, Vaughan TL, Hansten PD, Stanford JL, Risch HA, Gammon MD, Chow WH, Dubrow R, Ahsan H, Mayne ST, et al: Use of aspirin and other nonsteroidal anti-inflammatory drugs and risk of esophageal and gastric cancer. Cancer Epidemiol Biomarkers Prev 7: 97-102, 1998.

41. Vaughan TL, Dong LM, Blount PL, Ayub K, Odze RD, Sanchez CA, Rabinovitch PS and Reid BJ: Non-steroidal anti-inflammatory drugs and risk of neoplastic progression in Barrett's oesophagus: A prospective study. Lancet Oncol 6: 945-952, 2005.

42. González-Pérez A, Rodríguez LAG and LópezRidaura R: Effects of non-steroidal anti-inflammatory drugs on cancer sites other than the colon and rectum: A meta-analysis. BMC Cancer 3: 28 , 2003.

43. Liu JF, Jamieson GG, Wu TC, Zhu GJ and Drew PA: A preliminary study on the postoperative survival of patients given aspirin after resection for squamous cell carcinoma of the esophagus or adenocarcinoma of the cardia. Ann Surg Oncol 16: 1397-1402, 2009.

44. Frouws MA, Bastiaannet E, Langley RE, Chia WK, van Herk-Sukel MP, Lemmens VE, Putter $\mathrm{H}$, Hartgrink $\mathrm{HH}$, Bonsing BA, Van de Velde CJ, et al: Effect of low-dose aspirin use on survival of patients with gastrointestinal malignancies; an observational study. Br J Cancer 116: 405-413, 2017.

45. Macfarlane TV, Murchie P and Watson MC: Aspirin and other non-steroidal anti-inflammatory drug prescriptions and survival after the diagnosis of head and neck and oesophageal cancer Cancer Epidemiol 39: 1015-1022, 2015.

46. Bosetti C, Rosato V, Gallus S, Cuzick J and La Vecchia C: Aspirin and cancer risk: A quantitative review to 2011. Ann Oncol 23: 1403-1415, 2012.

47. Jankowski JAZ, de Caestecker J, Love SB, Reilly G, Watson P, Sanders S, Ang Y, Morris D, Bhandari P, Brooks C, et al: Esomeprazole and aspirin in Barrett's oesophagus (AspECT): A randomised factorial trial. Lancet 392: 400-408, 2018.

48. Spence AD, Busby J, Johnston BT, Baron JA, Hughes CM Coleman HG and Cardwell CR: Low-Dose aspirin use does not increase survival in 2 independent population-based cohorts of patients with esophageal or gastric cancer. Gastroenterology 154 849-860.e1, 2018.

49. Choi JH, Lee SH, Huh G, Chun JW, You MS, Paik WH, Ryu JK and Kim YT: The association between use of statin or aspirin and pancreatic ductal adenocarcinoma: A nested case-control study in a Korean nationwide cohort. Cancer Med 8: 7419-7430, 2019.

50. Sahasrabuddhe VV, Gunja MZ, Graubard BI, Trabert B, Schwartz LM, Park Y, Hollenbeck AR, Freedman ND and McGlynn KA: Nonsteroidal Anti-inflammatory drug use, chronic liver disease, and hepatocellular carcinoma. J Natl Cancer Inst 104: 1808-1814, 2012.

51. Coogan PF, Rosenberg L, Palmer JR, Strom BL, Zauber AG, Stolley PD and Shapiro S: Nonsteroidal anti-inflammatory drugs and risk of digestive cancers at sites other than the large bowel. Cancer Epidemiol Biomarkers Prev 9: 119-123, 2000.

52. Petrick JL, Sahasrabuddhe VV, Chan AT, Alavanja MC, Beane-Freeman LE, Buring JE, Chen J, Chong DQ, Freedman ND, Fuchs CS, et al: NSAID use and risk of hepatocellular carcinoma and intrahepatic cholangiocarcinoma: The liver cancer pooling project. Cancer Prev Res 8: 1156-1162, 2015.

53. Singh S, Singh PP, Roberts LR and Sanchez W: Chemopreventive strategies in hepatocellular carcinoma. Nat Rev Gastroenterol Hepatol 11: 45-54, 2013.
54. Hawk ET, Umar A and Viner JL: Colorectal cancer chemoprevention-an overview of the science 11 This article was prepared in our capacity as employees of the U.S. Federal Government. Gastroenterology 126: 1423-1447, 2004

55. Elwood PC, Gallagher AM, Duthie GG, Mur LA and Morgan G: Aspirin, salicylates, and cancer. Lancet 373: 1301-1309, 2009.

56. Pasche B, Wang M, Pennison M and Jimenez H: Prevention and treatment of cancer with aspirin: Where do we stand? Semin Oncol 41: 397-401, 2014.

57. Mahboubi Rabbani SMI and Zarghi A: Selective COX-2 inhibitors as anticancer agents: A patent review (2014-2018). Expert Opin Ther Pat 29: 407-427, 2019.

58. Poorani R, Bhatt AN, Dwarakanath BS and Das UN: COX-2, aspirin and metabolism of arachidonic, eicosapentaenoic and docosahexaenoic acids and their physiological and clinical significance. Eur J Pharmacol 785: 116-132, 2016.

59. Wang D and Dubois RN: Prostaglandins and cancer. Gut 55: 115-122, 2006

60. Chell S, Kaidi A, Williams AC and Paraskeva C: Mediators of PGE2 synthesis and signalling downstream of COX-2 represent potential targets for the prevention/treatment of colorectal cancer. Biochim Biophys Acta 1766: 104-119, 2006.

61. Chan AT, Ogino S and Fuchs CS: Aspirin and the risk of colorectal cancer in relation to the expression of COX-2. N Engl J Med 356: 2131-2142, 2007.

62. Zhang L, Yu J, Park BH, Kinzler KW and Vogelstein B: Role of BAX in the apoptotic response to anticancer agents. Science 290: 989-992, 2000

63. Zhang Z and Dubois RN: Par-4, a proapoptotic gene, is regulated by NSAIDs in human colon carcinoma cells. Gastroenterol 118: 1012-1017, 2000

64. Kashfi K and Rigas B: Non-COX-2 targets and cancer: Expanding the molecular target repertoire of chemoprevention. Biochem Pharmacol 70: 969-986, 2005.

65. Shureiqi I, Xu X, Chen D, Lotan R, Morris JS, Fischer SM and Lippman SM: Nonsteroidal anti-inflammatory drugs induce apoptosis in esophageal cancer cells by restoring 15-lipoxygenase-1 expression. Cancer Res 61: 4879-4884, 2001.

66. Elmore S: Apoptosis: A review of programmed cell death. Toxicol Pathol 35: 495-516, 2007.

67. McIlhatton MA, Tyler J, Burkholder S, Ruschoff J, Rigas B, Kopelovich L and Fishel R: Nitric Oxide-donating aspirin derivatives suppress microsatellite instability in mismatch repair-deficient and hereditary nonpolyposis colorectal cancer cells. Cancer Res 67: 10966-10975, 2007.

68. Rüschoff J, Wallinger S, Dietmaier W, Bocker T, Brockhoff G, Hofstädter F and Fishel R: Aspirin suppresses the mutator phenotype associated with hereditary nonpolyposis colorectal cancer by genetic selection. Proc Natl Acad Sci USA 95: 11301-11306, 1998.

69. Goel A, Chang DK, Ricciardiello L, Gasche C and Boland CR: A novel mechanism for aspirin-mediated growth inhibition of human colon cancer cells. Clin Cancer Res 9: 383-390, 2003.

70. Huang Z, Fang W, Liu W, Wang L, Liu B, Liu S and Liu S: Aspirin induces Beclin-1-dependent autophagy of human hepatocellular carcinoma cell. Eur J Pharmacol 823: 58-64, 2018.

71. Bhattacharya A and Eissa NT: Autophagy and autoimmunity crosstalks. Front Immunol 4: 88, 2013

72. Henry WS, Laszewski T, Tsang T, Beca F, Beck AH, McAllister SS and Toker A: Aspirin suppresses growth in PI3K-mutant breast cancer by activating AMPK and inhibiting mTORC1 signaling. Cancer Res 77: 790-801, 2017.

73. Liu W, Jiang Y, Sun J, Geng S, Pan Z, Prinz RA, Wang C, Sun J, Jiao X and Xu X: Activation of TGF- $\beta$-activated kinase 1 (TAK1) restricts Salmonella Typhimurium growth by inducing AMPK activation and autophagy. Cell Death Dis 9: 570, 2018.

74. Hardie DG, Ross FA and Hawley SA: AMP-Activated protein kinase: A target for drugs both ancient and modern. Chem Biol 19: 1222-1236, 2012.

75. Kostadinov RL, Kuhner MK, Li X, Sanchez CA, Galipeau PC, Paulson TG, Sather CL, Srivastava A, Odze RD, Blount PL, et al: NSAIDs modulate clonal evolution in Barrett's esophagus. PLoS Genet 9: e1003553, 2013.

76. Drew DA, Cao Y and Chan AT: Aspirin and colorectal cancer: The promise of precision chemoprevention. Nat Rev Cancer 16: 173-186, 2016.

77. Gala MK and Chan AT: Molecular pathways: Aspirin and Wnt signaling-a molecularly targeted approach to cancer prevention and treatment. Clin Cancer Res 21: 1543-1548, 2015. 
78. Yeomans ND, Lanas AI, Talley NJ, Thomson AB, Daneshjoo R, Eriksson B, Appelman-Eszczuk S, Långström G, Naesdal J, Serrano $\mathrm{P}$, et al: Prevalence and incidence of gastroduodenal ulcers during treatment with vascular protective doses of aspirin. Aliment Pharmacol Ther 22: 795-801, 2005.

79. Cayla G, Collet JP, Silvain J, Thiefin G, Woimant F and Montalescot G: Prevalence and clinical impact of Upper Gastrointestinal Symptoms in subjects treated with low dose aspirin: The UGLA survey. Int J Cardiol 156: 69-75, 2012.

80. Biondi-Zoccai GG, Lotrionte M, Agostoni P, Abbate A Fusaro M, Burzotta F, Testa L, Sheiban I and Sangiorgi G: A systematic review and meta-analysis on the hazards of discontinuing or not adhering to aspirin among 50,279 patients at risk for coronary artery disease. Eur Heart J 27: 2667-2674, 2006.

81. Baron JA, Senn S, Voelker M, Lanas A, Laurora I, Thielemann W, Bruckner A and McCarthy D: Gastrointestinal adverse effects of short-term aspirin use: A meta-analysis of published randomized controlled trials. Drugs R D 13: 9-16, 2013.

82. Cayla G, Collet JP, Silvain J, Thiefin G, Woimant F and Montalescot G: Prevalence and clinical impact of Upper Gastrointestinal Symptoms in subjects treated with low dose aspirin: The UGLA survey. Int J Cardiol 156: 69-75, 2012.

83. Yeomans ND and Naesdal J: Systematic review: Ulcer definition in NSAID ulcer prevention trials. Aliment Pharmacol Ther 27: 465-472, 2008

84. Cryer B and Feldman M: Effects of very low dose daily, long-term aspirin therapy on gastric, duodenal, and rectal prostaglandin levels and on mucosal injury in healthy humans. Gastroenterology 117: 17-25, 1999.

85. Papatheodoridis GV, Sougioultzis S and Archimandritis AJ: Effects of Helicobacter pylori and nonsteroidal anti-inflammatory drugs on peptic ulcer disease: Systematic review. Clin Gastroenterol Hepatol 4: 130-142, 2006.

86. Huang JQ, Sridhar S and Hunt RH: Role of Helicobacter pylori infection and non-steroidal anti-inflammatory drugs in peptic-ulcer disease: A meta-analysis. Lancet 359: 14-22, 2002.

87. Thorat MA and Cuzick J: Prophylactic use of aspirin: Systematic review of harms and approaches to mitigation in the general population. Eur J Epidemiol 30: 5-18, 2015.

88. Iwamoto J, Mizokami Y, Shimokobe K, Ito M, Hirayama T, Saito Y, Ikegami T, Honda A and Matsuzaki Y: Clinical features of gastroduodenal ulcer in Japanese patients taking low-dose aspirin. Dig Dis Sci 55: 2270-2274, 2010.

89. Garcia Rodriguez LA, Martin-Perez M, Hennekens $\mathrm{CH}$, Rothwell PM and Lanas A: Bleeding Risk with long-term low-dose aspirin: A systematic review of observational studies. PLoS One 11: e0160046, 2016.

90. McNeil JJ, Wolfe R, Woods RL, Tonkin AM, Donnan GA, Nelson MR, Reid CM, Lockery JE, Kirpach B, Storey E, et al: Effect of aspirin on cardiovascular events and bleeding in the healthy elderly. N Engl J Med 379: 1509-1518, 2018.

91. de Abajo FJ and García Rodríguez LA: Risk of upper gastrointestinal bleeding and perforation associated with low-dose aspirin as plain and enteric-coated formulations. BMC Clin Pharmacol 1: 1,2001.

92. Lanas A, Serrano P, Bajador E, Esteva F, Benito R and Sáinz R: Evidence of aspirin use in both upper and lower gastrointestinal perforation. Gastroenterology 112: 683-689, 1997.

93. Yamada A, Sugimoto T, Kondo S, Ohta M, Watabe H, Maeda S, Togo G, Yamaji Y, Ogura K, Okamoto M, et al: Assessment of the risk factors for colonic diverticular hemorrhage. Dis Colon Rectum 51: 116-120, 2008.

94. Lanas Á, Carrera-Lasfuentes P, Arguedas Y, García S, Bujanda L, Calvet X, Ponce J, Perez-Aísa Á, Castro M, Muñoz M, et al: Risk of upper and lower gastrointestinal bleeding in patients taking nonsteroidal anti-inflammatory drugs, antiplatelet agents, or anticoagulants. Clin Gastroenterol Hepatol 13: 906-912.e2, 2015.

95. Hirata Y, Kataoka H, Shimura T, Mizushima T, Mizoshita T, Tanida S, Kamiya T and Joh T: Incidence of gastrointestinal bleeding in patients with cardiovascular disease: Buffered aspirin versus enteric-coated aspirin. Scand J Gastroenterol 46 803-809, 2011.

96. Nagata N, Niikura R, Aoki T, Shimbo T, Kishida Y, Sekine K, Tanaka S, Watanabe K, Sakurai T, Yokoi C, et al: Colonic diverticular hemorrhage associated with the use of nonsteroidal anti-inflammatory drugs, low-dose aspirin, antiplatelet drugs, and dual therapy. J Gastroenterol Hepatol 29: 1786-1793, 2014 .
97. Reichert MC, Krawczyk M, Appenrodt B, Casper M, Friesenhahn-Ochs B, Grünhage F, Jüngst C, Zimmer V, Lammert $\mathrm{F}$ and Dauer M: Selective association of nonaspirin NSAIDs with risk of diverticulitis. Int J Colorectal Dis 33: 423-430, 2018.

98. Strate LL, Liu YL, Huang ES, Giovannucci EL and Chan AT: Use of aspirin or nonsteroidal anti-inflammatory drugs increases risk for diverticulitis and diverticular bleeding. Gastroenterology 140: 1427-1433, 2011.

99. O'Connor N, Dargan PI and Jones AL: Hepatocellular damage from non-steroidal anti-inflammatory drugs. QJM 96: 787-791, 2003.

100. McNeil JJ, Nelson MR, Woods RL, Lockery JE, Wolfe R, Reid CM, Kirpach B, Shah RC, Ives DG, Storey E, et al: Effect of aspirin on all-cause mortality in the healthy elderly. N Engl J Med 379: 1519-1528, 2018.

101. Burn J, Gerdes AM, Macrae F, Mecklin JP, Moeslein G, Olschwang S, Eccles D, Evans DG, Maher ER, Bertario L, et al: Long-term effect of aspirin on cancer risk in carriers of hereditary colorectal cancer: An analysis from the CAPP2 randomised controlled trial. Lancet 378: 2081-2087, 2011.

102. Würtz $M$ and Grove EL: Interindividual variability in the efficacy of oral antiplatelet drugs: Definitions, mechanisms and clinical importance. Curr Pharm Des 18: 5344-5361, 2012.

103. Rocca B and Petrucci G: Variability in the responsiveness to low-dose aspirin: Pharmacological and disease-related mechanisms. Thrombosis 2012: 376721, 2012.

104. Joharatnam-Hogan N, Cafferty F, Hubner R, Swinson D, Sothi S, Gupta K, Falk S, Patel K, Warner N, Kunene V, et al: Aspirin as an adjuvant treatment for cancer: Feasibility results from the Add-Aspirin randomised trial. Lancet Gastroenterol Hepatol 4: 854-862, 2019

105. Kaufman DW, Kelly JP, Wiholm BE, Laszlo A, Sheehan JE, Koff RS and Shapiro S: The risk of acute major upper gastrointestinal bleeding among users of aspirin and ibuprofen at various levels of alcohol consumption. Am J Gastroenterol 94: 3189-3196, 1999.

106. Hernández-Díaz S and García Rodríguez LA: Cardioprotective aspirin users and their excess risk of upper gastrointestinal complications. BMC Med 4: 22-20, 2006.

107. Bhatt DL, Scheiman J, Abraham NS, Antman EM, Chan FK, Furberg CD, Johnson DA, Mahaffey KW and Quigley EM; American College of Cardiology Foundation Task Force on Clinical Expert Consensus Documents: ACCF/ACG/AHA 2008 expert consensus document on reducing the gastrointestinal risks of antiplatelet therapy and NSAID use: A Report of the American College of Cardiology Foundation Task Force on Clinical Expert Consensus Documents. Circulation 118: 1894-1909, 2008

108. Kelly JP, Kaufman DW, Jurgelon JM, Sheehan J, Koff RS and Shapiro S: Risk of aspirin-associated major upper-gastrointestinal bleeding with enteric-coated or buffered product. Lancet 348: 1413-1416, 1996.

109. Lin KJ, Hernández-Díaz S and García Rodríguez LA: Acid suppressants reduce risk of gastrointestinal bleeding in patients on antithrombotic or anti-inflammatory therapy. Gastroenterology 141: 71-79, 2011.

110. Sylvester KW, Cheng JW and Mehra MR: Esomeprazole and aspirin fixed combination for the prevention of cardiovascular events. Vasc Health Risk Manag 9: 245-254, 2013

111. Lanas A, Polo-Tomas M and Casado-Arroyo R: The aspirin cardiovascular/gastrointestinal risk calculator-a tool to aid clinicians in practice. Aliment Pharmacol Ther 37: 738-748, 2013.

112. Mo C, Sun G, Lu ML, Zhang L, Wang YZ, Sun X and Yang YS: Proton pump inhibitors in prevention of low-dose aspirin-associated upper gastrointestinal injuries. World J Gastroenterol 21: 5382-5392, 2015.

113. Scally B, Emberson JR, Spata E, Reith C, Davies K, Halls H, Holland L, Wilson K, Bhala N, Hawkey C, et al: Effects of gastroprotectant drugs for the prevention and treatment of peptic ulcer disease and its complications: A meta-analysis of randomised trials. Lancet Gastroenterol Hepatol 3: 231-241, 2018.

114. Whellan DJ, Goldstein JL, Cryer BL, Eisen GM, Lanas A, Miller AB, Scheiman JM, Fort JG, Zhang Y and O'Connor C: PA32540 (a coordinated-delivery tablet of enteric-coated aspirin $325 \mathrm{mg}$ and immediate-release omeprazole $40 \mathrm{mg}$ ) versus enteric-coated aspirin $325 \mathrm{mg}$ alone in subjects at risk for aspirin-associated gastric ulcers: Results of two 6-month, phase 3 studies. Am Heart J 168: 495-502.e4, 2014 
115. Martín Merino E, Johansson S, Nagy P and García Rodríguez LA Effect of baseline gastrointestinal risk and use of proton pump inhibitors on frequency of discontinuation of aspirin for secondary cardiovascular prevention in united kingdom primary care. Am J Cardiol 112: 1075-1082, 2013.

116. Dey AB: World report on ageing and health. Indian J Med Res 145: 150, 2017.

117. Hull MA, Sprange K, Hepburn T, Tan W, Shafayat A, Rees CJ, Clifford G, Logan RF, Loadman PM, Williams EA, et al: Eicosapentaenoic acid and aspirin, alone and in combination, for the prevention of colorectal adenomas (seAFOod Polyp Prevention trial): A multicentre, randomised, double-blind, placebo-controlled, 2x2 factorial trial. Lancet 392: 2583-2594, 2018.

118. Cole BF, Logan RF, Halabi S, Benamouzig R, Sandler RS, Grainge MJ, Chaussade S and Baron JA: Aspirin for the chemoprevention of colorectal adenomas: Meta-analysis of the randomized trials. J Natl Cancer Inst 101: 256-266, 2009.

119. Cook NR, Lee IM, Zhang SM, Moorthy MV and Buring JE: Alternate-day, low-dose aspirin and cancer risk: Long-term observational follow-up of a randomized trial. Ann Intern Med 159: 77-85, 2013.

120. Kuan YC, Huang KW, Lin CL, Luo JC and Kao CH: Effects of aspirin or clopidogrel on colorectal cancer chemoprevention in patients with type 2 diabetes mellitus. Cancers (Basel) 11: 1468, 2019.

121. Rothwell PM, Wilson M, Price JF, Belch JF, Meade TW and Mehta Z: Effect of daily aspirin on risk of cancer metastasis: A study of incident cancers during randomised controlled trials. Lancet 379: 1591-1601, 2012.

122. Chan FK, Leung Ki EL, Wong GL, Ching JY, Tse YK, Au KW, Wu JC and Ng SC: Risks of bleeding recurrence and cardiovascular events with continued aspirin use after lower gastrointestinal hemorrhage. Gastroenterology 151: 271-277, 2016.
123. Casado Arroyo R, Polo-Tomas M, Roncales MP, Scheiman J and Lanas A: Lower GI bleeding is more common than upper among patients on dual antiplatelet therapy: Long-term follow-up of a cohort of patients commonly using PPI co-therapy. Heart 98: 718-723, 2012

124. Smecuol E, Pinto Sanchez MI, Suarez A, Argonz JE, Sugai E, Vazquez H, Litwin N, Piazuelo E, Meddings JB, Bai JC and Lanas A: Low-dose aspirin affects the small bowel mucosa: Results of a pilot study with a multidimensional assessment. Clin Gastroenterol Hepatol 7: 524-529, 2009.

125. Moore RA, Derry S and McQuay HJ: Faecal blood los with aspirin, nonsteroidal anti-inflammatory drugs and cyclo-oxygenase-2 selective inhibitors: Systematic review of randomized trials using autologous chromium-labelled erythrocytes. Arthritis Res Ther 10: R7, 2008.

126. Endo H, Higurashi T, Hosono K, Sakai E, Sekino Y, Iida H, Sakamoto Y, Koide T, Takahashi H, Yoneda M, et al: Efficacy of Lactobacillus casei treatment on small bowel injury in chronic low-dose aspirin users: A pilot randomized controlled study. J Gastroenterol 46: 894-905, 2011.

127. Montalto M, Gallo A, Curigliano V, D'Onofrio F, Santoro L, Covino M, Dalvai S, Gasbarrini A and Gasbarrini G: Clinical trial: The effects of a probiotic mixture on non-steroidal anti-inflammatory drug enteropathy-a randomized, double-blind, cross-over, placebo-controlled study. Aliment Pharmacol Ther 32: 209-214, 2010.

This work is licensed under a Creative Commons Attribution-NonCommercial-NoDerivatives 4.0 International (CC BY-NC-ND 4.0) License. 